\title{
Indonesian Bridal Makeup Subject: E-learning Implementation
}

\author{
Dindy Sinta Megasari, Ita Fatkhur Romadhoni \\ Department of Home Economics \\ Universitas Negeri Surabaya \\ Surabaya, Indonesia \\ dindymegasari@unesa.ac.id
}

\begin{abstract}
The purpose of this study is to determine the implementation of Semester Learning Plan (Rencana Pembelajaran Semester/ RPS) and to know the completeness of learning outcomes using e-learning in the Indonesian bridal make up courses. This research is done through two stages of developmental processes; define and develop. The define stage is done to prepare the initial design, while the develop stage is done to validate and develop the device to produce the test device in the form of a limited trial on 25 students of Education Degree of Makeup at State University of Surabaya (Universitas Negeri Surabaya/ UNESA). Three meetings were observed based on the implementation of the Lesson Plans. There were 11 aspects on the $1^{\text {st }}$ meeting which 2 of them were not implemented. The $2^{\text {nd }}$ and $3^{\text {rd }}$ meetings covered all aspects of instructional learning. This study shows that the students have developed the learning outcomes based on the e learning process proven by the posttest result, 11 indicators are completed. It indicates that the students master the process skills after systematically taught.
\end{abstract}

\section{Keywords-e-learning; Indonesian bridal; makeup}

\section{INTRODUCTION}

Educators have available variety of instructional media and teaching formats which are used to present information. Selecting the suitable medium for the learners is an important consideration [1]. The use of telecommunication technology for learning activities in Indonesian universities is increasingly conducive based on the Ministerial Decree's judgment by the Ministry of National Education in 2013 which encourages conventional universities to organize distance education. Elearning will create a different activity with traditional class which becomes new challenges for both teachers and learners [2]. As young teachers, we have to be responsive to the new things and need to approach education from a new perspective [3]. Some people define new users or incorporate a particular working instrument into this new form of experience which cannot be achieved simply by simple usage [4]. This study aims to accommodate the needs of lecturers and students in taking part on the development of science and technology through the implementation of e-learning in bridal makeup courses Indonesia. E-learning is considered to be able to provide wider space for students in the process of improving the quality, both in their cognitive and psychomotor.

Interactive learning is focused on the integrated e-learning and face to face learning to ensure that the process of teaching and learning can stimulate learners' interests, report their progress and have tutors, to provide their feedback and guide the learners to the expected targets [5]. Based on the description above, we want to know the implementation of the Semester Learning Plan in the teaching and learning process and the completeness of the learning outcomes by using elearning in bridal makeup courses Indonesia.

In the sense of implementation which reflects the design, it is very important to understand the lecturers who involved in the teaching and learning process as the main core to understand the design of e-learning learning properly and correctly. Planning, designing the correct source of e-learning and knowledge of usage characteristics are also important for the successful e-learning [6]. There are at least 3 (three) elearning functions of classroom instruction, (Siahaan, 2014): (1) supplements (additional), i.e. if the students have the freedom of choice; (2) complement (complementary), that is if the electronic learning materials are programmed to complement the learning materials received by students in the classroom; (3) substitution (substitute), that is if e-learning is used as a substitute for learning activities, for example by using models of learning activities. There are 3 (three) alternative model choices: (1) fully face-to-face (conventional), (2) partially face to face and partly via internet, or even (3) entirely via internet [7].

According to research results, Joi L. Moore (2010) elearning is an abbreviation of Electronic Learning, is a new way in teaching and learning process that uses electronic media, especially the internet as a learning system [8]. Elearning is provided only through computer tools but in this research, students can access e-learning through android devices. Four-D Model device development models are suggested by Sivasailam Thiagarajan, Dorothy S. Semmel, and Melvyn I. Semmel (1974). This model consists of 4 development stages namely Define, Design, Develop, and Disseminate. However, this study is only limited on the $3^{\text {rd }}$ stage.

Stage 1: Define, it includes learner analysis, task analysis, concept analysis and specifying instructional objectives. Phase II: Design, it covers criterion test construction, media selection, format selection and initial design according to the selected format. Phase III: Develop, it produces expert appraisal and developmental testing. The purpose of this stage is to produce the final form of learning devices after a revision 
based on the input of expertise/ practitioners and test results data.

There are many researches who discussed about e-learning so as to provide considerable benefits include: The results of research conducted by Signe (2015) shows that e-learning is an effective learning media, but it needs to be underlined that the need for an adequate internet network in a learning environment is essential [9]. The results of research conducted by Joi et al (2013) through the validity and reliability test, sewing skirt instrument has been fulfilled as a good instrument with reliability index of 0.87 . Assessment procedures are developed from the socialization of the instrument, looking at the instrument, and the technical implementation.

The research conducted by Yunhui Zhuang (2017) shows that all these e-Learning technologies for being used in Hong Kong's higher education help both the students and the teacher to enhance teaching and learning experiences, and to broaden students' learning horizons. Moreover, with the help of such technologies, instructors are empowered with handful resources so that they can further enrich students' learning experiences through interactive classroom teaching [10].

\section{METHOD}

This is a research that develops e-learning based on the learning media. The subjects of the study are undergraduate students of Education of Makeup Class in the academic year of 2014, consists of 25 students who take Indonesian bridal makeup course. The research procedures begin with the development of tools consisting of RPS, LKM/ Student worksheet, Student Teaching Materials, developed using 4D models (four D models). The design of e-learning media development in this research as follows.

Research variables related to the feasibility of learning tools include validation of RPS, Teaching Materials and MFIs. And the variables related to the results of experimental learning tools include the implementation of RPS, student activities, lecturer activities, process skills and student learning outcomes.

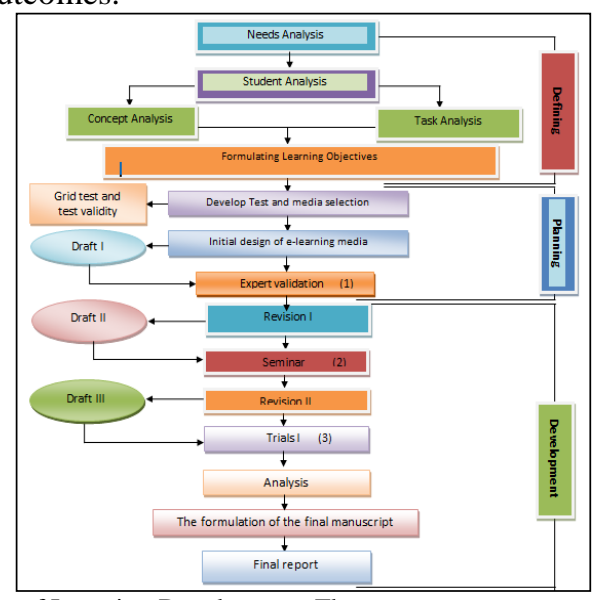

Fig. 1. Picture of Learning Development Flow

\section{RESULTS AND DISCUSSION}

\section{A. Learning Implementation Process}

By using e-learning, it showed that in preliminary activities, aspects of conveying learning objectives / indicators are rated very well (4.5). This illustrates that the lecturer stressed very well to the students related to the materials and activities which were presented to the students which becomes the characteristic of the e-learning model.

In the main activities, the guiding aspect of accessing elearning plan individually was rated fairly well (3.5). This assessment was obtained based on the observation that lecturers still had difficulty in guiding the activities due to the limited number of laptops. This is different from other main activities which is on the guiding aspects of analyzing and concluding that received a rating with very good category (4.5). This is because students became more familiar after login e-learning so that students felt easier in making conclusions. The author argues that in general, e-learning model is applicable in the Education Department of Makeup at the Undergraduate Degree (Program Studi S1 Pendidikan Tata Rias), although there are some aspects which need more emphasis, especially on the speed and stability of accessing the internet because the students are required to think independently in this aspect.

At the third meeting, the RPS was totally implemented (100\%), means that all aspects were done. In general, RPS in the data collection was well achieved.

\section{B. Completeness of learning outcomes}

The results of process skills in pretest includes: (a) opening e-learning web, (b) registering member, (c) determining the course of makeup of bridal face, (d) carrying out bridal makeup activity based on table planning procedure (observation and presenting data in tables that have been planned independently), (f) doing the task independently, and (g) drawing the conclusion of the practice result. This shows that students had not been able to master process skills. After attending a series of e-learning access activities (85\%), students were able to carry out the process skills according to the key answers.

Psychomotor results show that (25) students carried out performance tests in accordance with the specified work details. It can be concluded that the completeness of psychomotor indicators had been achieved.

The author argues that skills process actually can be applied to students, but in the implementation process still needs a special emphasis. This is because students generally work kinetically so an exercise in thinking skills is necessary. 


\section{CONCLUSION}

\section{A. The results of the implementation}

By implementing RPS during the teaching and learning process based on e-learning, showed that in the first meeting, from 11 aspects of the implementation of RPS, only 2 aspects were not implemented, so the percentage of implementation of RPS at the first meeting was $92 \%$, while the compatibility between the two observers was $92 \%$. At the second meeting, the implementation of RPS was $79 \%$, because of from the 26 aspects, only 22 aspects were implemented. At the second meeting, the compatibility between the two observers was $79 \%$. At the third meeting, the implementation of RPS was $100 \%$, meaning that all aspects were well implemented. In general, RPS was done well and had practicality, effectiveness, and validity.

\section{B. Completeness of student learning outcomes}

After e-learning developed, it showed that the product of achievement indicators on pretest is still below $70 \%$ which means that it had not been achieved. After conducting elearning, posttest result showed that from 10 product indicators, there were 3 indicators completed (90\%). Among these 10 indicators, include re-defining e-learning, identifying the types of e-learning, identifying the requirements of the lecture, exposing the material in e-learning, identifying the access requirements of e-learning at UNESA, how to download the material, identifying the available types of material files, how to make a change of material, how to display video feature and how to make bookmark result of makeup practice. This indicates that students master process skill after systematically taught.

Based on the results of research, it is recommended to improve the ability of lecturers in mastering e-learning needs which results to the improvement of the student learning outcomes. Further, students are expected to add an onlinebased insight rather than BAM that has been provided as well as media outside of the material taught in the classroom. It is very helpful to solve problems that generally occur in the field. The applicable planning material by using e learning on Makeup students need to be developed further. Finally, the students should be more independent in implementing $\mathrm{e}$ learning activity and enriching the materials.

\section{REFERENCES}

[1] Rodgers, David L, "The Effect of Instructional Media on Learner Motivation", Int'l j of instructional media, vol.32(4), 2005, pp. 333-342.

[2] Andreea-Maria Tirziu, Catalin Vrabie, "Education 2.0:E-Learning Methods", Procedia-Social and Behavioral Sciences 186 (2015), pp. 376-380.

[3] Chi-Un Lei, Elizabeth Oh, "Scale Out Teaching, scale Up Learning: Profesional Development For E-Teaching/Learning", International Conference on Teching, Assessment, and Learning for Engineering (TALE) 7-9 December 2016, pp.978-1-5090-5598-2.

[4] Bedrule-Grigoruta, M.V., Rusua, M.L, "Considerations about e-learning tools for adult education", Proc, Soc, Behav, Sci 142, 2014, pp.749-754.

[5] Victor Chang, "E-learning for academia and industry", Leeds Beckett University, 22 December 2015, pp.1475.

[6] Alevriadou, A., Urh, M., Vukovic, G., Jereb, E., Pintar, R., "The model for introduction of gamification into e-learning in higher education", In: $7^{\text {th }}$ World Conferece on Education Sciences, vol.197, 2015, pp.388-397.

[7] Jolly T.Holden, Philip J.L Westfall, An Instructional Media Selection Guide for Distance Learning, United States Distance Learning Association, 2009.

[8] Joi L, Moore, Camille Dickson-Deane, Krista Galyen, “e-learning, online learning, and distance learning environments: Are they the same?",March 2011, pp. 129-135.

[9] Signe Schack Noesgaard, "The effectiveness of e-learning: An Explorative and Integrative Review of the Definitions, Methodologies and Factors that Promote e-learning effectiveness", the electronic journal of e-learning vol.13, Issue 4, 2015, pp. 278-290.

[10] Yunhui Zhuang, He Ma, Haoran Xie, Alvin Chung Man Leung, Gerhard P. Hancke, Fu lee Wang, "When Innovation Meets Evolution: An Extensive Study of Emerging e-learning technologies for Higher Education in Hong Kong”, 2017, pp.574-584. 